\title{
Effects of various pretreatments on biohydrogen production from sewage sludge
}

\author{
XIAO BenYi \& LIU JunXin ${ }^{\dagger}$ \\ Research Center for Eco-Environmental Sciences, Chinese Academy of Sciences, Beijing 100085, China
}

The sewage sludge of wastewater treatment plant is a kind of biomass which contains many organics, mainly carbohydrates and proteins. Four pretreatments, acid pretreatment, alkaline pretreatment, thermal pretreatment and ultrasonic pretreatment, were used to enhance biohydrogen production from sewage sludge. The experimental results showed that the four pretreatments could all increase the soluble chemical oxygen demand (SCOD) of sludge and decrease the dry solid (DS) and volatile solid (VS) because the pretreatments could disrupt the floc structure and even the microbial cells of sludge. The results of batch anaerobic fermentation experiments demonstrated that all of the four pretreatments could select hydrogen-producing microorganisms from the microflora of sludge and enhance the hydrogen production. The hydrogen yield of the alkaline pretreated sludge at initial $\mathrm{pH}$ of $11.5 \mathrm{was}$ the maximal (11.68 $\mathrm{mL} \mathrm{H}_{2} / \mathrm{g} \mathrm{VS}$ ) and that of the thermal pretreated sludge was the next $\left(8.62 \mathrm{~mL} \mathrm{H}_{2} / \mathrm{g} \mathrm{VS}\right)$. The result showed that the hydrogen yield of pretreated sludge was correlative with its SCOD. The hydrogen yields of acid pretreated sludge and alkaline pretreated sludge were also influenced by their initial $\mathrm{pH}$. No methane could be detected in the anaerobic fermentation of alkaline pretreated sludge and thermal pretreated sludge, which suggested that these pretreatments could fully inhibit the activity of methanogens. The volatile fatty acids (VFA) production in anaerobic fermentation of alkaline pretreated sludge was the maximum and the next is that of thermal pretreated sludge.

biohydrogen production, effects, pretreatment, sewage sludge

The sewage sludge of wastewater treatment plants is composed largely of organic matters (for example, carbohydrates and proteins) ${ }^{[1]}$. Anaerobic digestion technique has been traditionally employed to treat sludge and obtain methane ${ }^{[2,3]}$. Hydrogen is an intermediate product of the anaerobic sludge digestion, but unstable, because it will be quickly consumed by hydrogen-consuming bacteria, such as methanogens and sulfate-reducing bacteria ${ }^{[2]}$.

In order to harvest hydrogen from anaerobic sludge digestion, the activity of consuming-hydrogen bacteria must be inhibited ${ }^{[3,4]}$. In other words, the anaerobic process must be stopped at the hydrogen and acetic acid forming stage and the consumption of hydrogen must be blocked. At laboratory scale, the following methods for limiting hydrogen consumption are used: (1) Operation at a short HRT to wash out hydrogen-consuming bacte- ria; (2) operation at low $\mathrm{pH}$ to inhibit them and (3) inoculation with pretreated sludge ${ }^{[4]}$. Some hydrogenproducing microorganisms could form endospores, which are very resistant to heating or harmful chemicals including acid and alkaline and cannot be killed easily, while most of the hydrogen-consuming species do not have theis characteristic. Once favorable conditions return, those spores germinate and become vegetative cells $^{[5,6]}$. So, it is possible to use some pretreatments to screen hydrogen-producing species. The methods of pretreatment include thermal pretreatment ${ }^{[4,6,7]}$, acid pretreatment, alkaline pretreatment ${ }^{[4]}$, and so on.

Received March 20, 2008; accepted July 3, 2008 doi: 10.1007/s11434-009-0100-Z

†Corresponding author (email: jxliu@rcees.ac.cn)

Supported by the National Natural Science Foundation of China (Grant No. 50621804) 
On the other hand, most of the organics presented in sewage sludge are enclosed within the microbial cell wall ${ }^{[1]}$ and the hydrolysis step is considered as the ratelimiting step in the overall anaerobic digestion process ${ }^{[2]}$. Some pretreatment methods, such as thermal pretreatment and alkaline pretreatment, have been used to disrupt the microbial cells and release the organics to liquid so as to enhance the anaerobic digestion of sludge ${ }^{[1,8,9]}$ and biohydrogen production of sludge ${ }^{[10-14]}$. For example, Cai et al. ${ }^{[10]}$ utilized alkaline pretreatment to enhance hydrogen production from sewage sludge.

As mentioned above, sewage sludge has been used to produce hydrogen by anaerobic fermentation. But most studies dealt with a single pretreatment in comparison with non-pretreatment. Although Wang et al. ${ }^{[13,14]}$ had used four kinds of pretreated (ultrasonic, acidified, sterilized, frozen/thawed) sludge to produce hydrogen by Clostridium sp., no report has been published about various pretreatment on hydrogen production from sewage sludge by anaerobic fermentation without extraseeds. Accordingly, the objective of this study was to investigate the effects of four pretreatments (acid, alkaline, thermal and ultrasonic pretreatments) on hydrogen production from sewage sludge by anaerobic fermentation without extra-seeds.

\section{Materials and methods}

\subsection{Pretreatments of sludge}

The raw sludge (RS) used in the study was obtained from the aeration tank of a municipal wastewater treatment plant of Beijing, China, whose design capacity is $30000 \mathrm{~m}^{3} / \mathrm{d}$. The $\mathrm{pH}$ value of the sludge was about 7.16 $( \pm 0.2)$. The chemical oxygen demand (COD) of the sludge was $11,500 \mathrm{mg} / \mathrm{L}$ and the soluble chemical oxygen demand (SCOD) was $113.7 \mathrm{mg} / \mathrm{L}$. The dry solid (DS) and volatile solid (VS) of the sludge were $8,960 \mathrm{mg} / \mathrm{L}$ and $6190 \mathrm{mg} / \mathrm{L}$, respectively. The sludge was stored at $4^{\circ} \mathrm{C}$ before being used.

Four methods (acid, alkaline, thermal and ultrasonic pretreatments) were used to treat the sludge before they are used to anaerobic fermentation.

Acid pretreatment. The $\mathrm{pH}$ of the sludge sample were adjusted to $2.0 \pm 0.1$ and stabilized for 5 min under stirring with $6 \mathrm{~mol} / \mathrm{L}$ hydrochloric acid. The pretreated sample was acid pretreated sludge (AS).

Alkaline pretreatment. The $\mathrm{pH}$ of sludge sample was adjusted to $12.0 \pm 0.1$ and also stabilized for $5 \mathrm{~min}$ under stirring with $6 \mathrm{~mol} / \mathrm{L}$ sodium hydroxide. The pretreated sample was alkaline pretreated sludge or basified sludge (BS).

Thermal pretreatment. The sludge sample was autoclaved at $121^{\circ} \mathrm{C}$ and $1.2 \mathrm{kgf} / \mathrm{cm}^{2}$ (VARIOKLAV steam sterilizer, 300/400/500 EP) for $30 \mathrm{~min}$. The pretreated sample was thermal pretreated sludge (TS).

Ultrasonic pretreatment. The ultrasonic pretreatment was performed with the help of a cell-breaker (SONICATOR-JY92-2D2, Xinzhi Inc., China) at a frequency of $20 \mathrm{kHz}^{[11,12]}$. The sludge sample $(250 \mathrm{~mL})$ was placed in a $300 \mathrm{~mL}$ graduated flask with the ultrasonic probe positioned in $3 \mathrm{~cm}$ under the surface of sludge. The sonication time was $30 \mathrm{~min}$ and the sonication power was $200 \mathrm{~W}$. During sonication, the temperature of sludge was not controlled and increased from $16^{\circ} \mathrm{C}$ to $41^{\circ} \mathrm{C}$. The pretreated sludge was ultrasonic sludge (US).

$\mathrm{AS}$ and BS were stored at ambient temperature $\left(15^{\circ} \mathrm{C}-24^{\circ} \mathrm{C}\right)$ for $12 \mathrm{~h}$ to enhance the effect of pretreatments, while TS and US were stored at ambient temperature $\left(15^{\circ} \mathrm{C}-24^{\circ} \mathrm{C}\right)$ for $3 \mathrm{~h}$ to cool the pretreated sludge.

\subsection{Anaerobic fermentation of the pretreated sludge}

Before the pretreated sludge samples were used to anaerobic fermentation, the $\mathrm{pH}$ of parts of AS and BS was adjusted to $7.0 \pm 0.1$ with $6 \mathrm{~mol} / \mathrm{L}$ sodium hydroxide or $6 \mathrm{~mol} / \mathrm{L}$ hydrochloric acid. The pretreated sludge samples $(150 \mathrm{~mL})$ were added into $300 \mathrm{~mL}$ plexiglass digesters, respectively. No other material was added in the digesters. The digesters were equipped with two ports for gas and sludge sampling. The headspaces and the liquid phases of the digesters were flushed with nitrogen to provide an anaerobic environment. The digesters were quickly sealed and placed on a shaker (HKZ-C, China) with $140-150 \mathrm{rpm}$ at $37 \pm 1{ }^{\circ} \mathrm{C}$. The $\mathrm{pH}$ of the tested sludge samples is shown in Table 1. As control, the RS samples with $\mathrm{pH}$ being $2.5,7.0$ and $11.5( \pm 0.1)$, were also anaerobicly fermented (Table 1). Tests of the same sludge were carried out in triplicate and all the results were the mean value of the replicated analyses.

\subsection{Analyses}

Biogas production was measured periodically by displacement of saturated aqueous $\mathrm{NaCl}$ with $5 \% \mathrm{H}_{2} \mathrm{SO}_{4}$ in a graduated cylinder ${ }^{[15]}$. The biogas in the headspace of digesters was sampled with a $1 \mathrm{~mL}$ gastight syringe. The 


\begin{tabular}{|c|c|c|c|c|c|c|c|c|c|}
\hline No & 1 & 2 & 3 & 4 & 5 & 6 & 7 & 8 & 9 \\
\hline Sludge sample & RS & RS & RS & AS & AS & BS & BS & TS & US \\
\hline Initial pH & 2.5 & 7.0 & 11.5 & 2.5 & 7.0 & 7.0 & 11.5 & 6.8 & 6.9 \\
\hline SCOD (mg/L) & 354.5 & 113.7 & 899.4 & 765.6 & 486.8 & 1085.4 & 3048.6 & 2442.2 & 1484.8 \\
\hline
\end{tabular}

hydrogen contents of biogas were analyzed by a gas chromatograph (GC-122, China) equipped with a thermal conductivity detector (TCD) and a $2 \mathrm{~m}$ stainless column packed with activated carbon (60-80 mesh). Nitrogen was used as the carrier gas with a flow rate of $30 \mathrm{~mL} / \mathrm{min}$. The content of methane in the biogas was analyzed by another gas chromatograph (Agilent 6890, America) equipped with a flame ionization detector (FID) and a $30 \mathrm{~m}$ capillary column (HP-5). Nitrogen was also used as carrier gas with a flow rate of 30 $\mathrm{mL} / \mathrm{min}$.

The sludge was sampled with a $5 \mathrm{~mL}$ gastight syringe. The concentrations of volatile fatty acids (VFA) in the sludge were analyzed using another gas chromatograph (Shimadzu GC-9A, Japan) equipped with a FID and a 1 $\mathrm{m}$ glass column packed with chromosorb 101 (60-80 mesh). The carrier gas was nitrogen at flow rate of 50 $\mathrm{mL} / \mathrm{min}$. The $\mathrm{pH}$ of sludge was measured by a $\mathrm{pH}$ meter (PHS-3C, China). The COD and SCOD of sludge were analyzed by COD detector (HACH 2800 America). The samples were filtered through a $0.45 \mu \mathrm{m}$ membrane before determining the SCOD. Soluble proteins in the liquid phase were measured by the Lowry's method using bovine serum albumin as a standard solution ${ }^{[16]}$, and soluble carbohydrates by the phenol-sulfuric acid method using glucose as a standard solution ${ }^{[17]}$. The DS and VS of sludge samples were determined according to APHA standard methods ${ }^{[18]}$.

\subsection{Kinetic analysis}

The modified Gompertz equation (eq. (1)) was used to fit the experimental data of accumulative hydrogen production $^{[19]}$.

$$
H(t)=P \times \exp \left\{-\exp \left[\frac{R_{m} e}{P}(\lambda-t)+1\right]\right\},
$$

where $H(t)$ is the accumulative hydrogen production $(\mathrm{mL})$ during the fermentation time $t(h), P$ the hydrogen production potential $(\mathrm{mL}), R_{m}$ the maximum production rate $(\mathrm{mL} / \mathrm{h}), \lambda$ the lag-phase time $(h)$, and $e$ is 2.718281828. The values of $P, R_{m}$ and $\lambda$ were determined by best fitting the hydrogen producing data for Eq. 1 using the Matlab $6.5^{[20]}$. The maximum specific hydrogen production rate $\left(\mathrm{mL} \mathrm{H}_{2} / \mathrm{g} \mathrm{VS} \cdot \mathrm{h}\right)$ was calculated by dividing $R_{m}$ by the initial sludge VS. The hydrogen yield ( $\mathrm{mL} \mathrm{H}_{2} / \mathrm{g}$ VS) was calculated by dividing $P$ by the quantity of sludge (VS) added in the digesters.

\section{Results and discussion}

\subsection{Effects of various pretreatments on sludge}

Because the mechanisms of the four pretreatments are different ${ }^{[21]}$, the impacts of these pretreatments on the sludge are also different. Table 2 summarizes the effects of the four pretreatments on the sludge. Because these pretreatments could disrupt part of the floc structures and the microbial cells of sludge ${ }^{[1]}$, some microbial matters were released into water and conversed from insoluble ones to soluble ones after pretreatment. Table 2 shows that all of the four pretreatments could decrease the DS and VS of sludge and increase the SCOD concentration. But their effects were different. The SCOD of BS was the maximal $(3048.6 \mathrm{mg} / \mathrm{L})$ and that of AS was the minimal (only $765.6 \mathrm{mg} / \mathrm{L}$ ). The results of DS and VS were reverse to those of SCOD. Since the content of soluble proteins and soluble carbohydrates could reach $70 \%-80 \%$ of SCOD, they were the major com-

Table 2 Effects of four pretreatments on some characteristics of sludge

\begin{tabular}{|c|c|c|c|c|c|c|}
\hline & $\mathrm{pH}$ & $\mathrm{DS}(\mathrm{g} / \mathrm{L})$ & VS (g/L) & $\mathrm{SCOD}(\mathrm{mg} / \mathrm{L})$ & $\operatorname{Car}^{\mathrm{a})}(\mathrm{mg} / \mathrm{L})$ & $\operatorname{Pro}^{\text {b) }}(\mathrm{mg} / \mathrm{L})$ \\
\hline RS & 7.16 & 8.96 & 6.19 & 113.72 & 24.23 & 26.76 \\
\hline AS & 3.09 & 8.15 & 6.08 & 765.61 & 93.42 & 347.93 \\
\hline BS & 11.8 & 6.70 & 3.79 & 3048.63 & 270.31 & 2085.36 \\
\hline TS & 6.80 & 7.55 & 4.74 & 2442.05 & 377.45 & 1367.19 \\
\hline US & 6.90 & 7.92 & 5.84 & 1484.80 & 135.25 & 569.26 \\
\hline
\end{tabular}

a) Soluble carbohydrates; b) soluble proteins. 
ponents of the soluble matters in the pretreated sludge. In addition, the maximal content of soluble carbohydrates and soluble proteins was achieved by TS and BS, respectively.

\subsection{Production of hydrogen}

The hydrogen production of the four kinds of pretreated sludge in anaerobic fermentation is shown in Figure 1. The hydrogen yield of BS at initial $\mathrm{pH}$ of 11.5 was the maximal (11.68 $\left.\mathrm{mL} \mathrm{H}_{2} / \mathrm{g} \mathrm{VS}\right)$ and the next was that of TS $\left(8.62 \mathrm{~mL} \mathrm{H}_{2} / \mathrm{g} \mathrm{VS}\right)$, while the anaerobic fermentation of some sludge samples did not produce hydrogen, i.e., $\mathrm{AS}$ and RS at initial pH of 2.5. According to Figure1, hydrogen was produced in the first stage of fermentation and consumed in the sequent stage, which was correlative with the growth of the hydrogen-producing bacteria and hydrogen-consuming ones in the sludge, respectively ${ }^{[22]}$. The differences of the experimental conditions, such as sewage sludge, initial $\mathrm{pH}$ and reactor form, were the reasons causing the differences of the hydrogen yields between this study and the literatures. Figure 1 also shows that the effect of initial $\mathrm{pH}$ on the hydrogen yield of four sludge samples was significant because high $\mathrm{pH}$ could further disrupt the microbial cell of sludge ${ }^{[10,12]}$. For example, the hydrogen yield of BS at

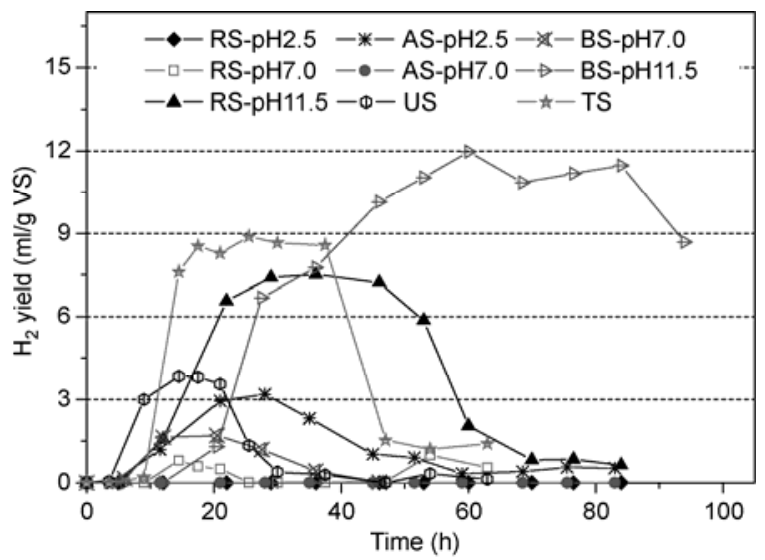

Figure 1 Hydrogen yield of various pretreated sludge samples at various initial $\mathrm{pH}$. initial $\mathrm{pH}$ of 11.5 was $11.68 \mathrm{~mL} \mathrm{H} / \mathrm{g} \mathrm{VS}$, while that at initial $\mathrm{pH}$ of 7.0 was only $1.46 \mathrm{~mL} \mathrm{H}_{2} / \mathrm{g}$ VS. These experimental results suggested that all of the four pretreatments could enhance hydrogen production from sewage sludge by anaerobic fermentation.

Table 3 summarizes the three kinetic parameters $(P$, $R_{m}$ and $\lambda$ ), hydrogen yield and maximum specific hydrogen production rate (MSHPR), for biohydrogen production from all sludge samples at various initial $\mathrm{pH}$. The results showed that those parameters were influenced by the pretreatments and the initial $\mathrm{pH}$ of sludge samples. For example, the hydrogen production potential $(P)$ of $\mathrm{BS}$ at initial $\mathrm{pH}$ of 11.5 was $10.84 \mathrm{~mL}$ (the maximum) while that of US was $3.56 \mathrm{~mL}$ and that of BS at initial $\mathrm{pH}$ of 7.0 was only $1.36 \mathrm{~mL}$. It was similar for the other parameters. The difference of the lag-phase time suggested that the effects of the four pretreatments on the growth of the selected hydrogen-producing bacteria were different ${ }^{[19]}$.

For biohydrogen production, the soluble organics are very important since the hydrogen-producing microorganisms need use them to grow and produce hydrogen. The soluble organics in the sludge can be presented by the initial SCOD (Table 1). Table 1 shows that the initial SCOD of the pretreated sludge samples was affected by the pretreatment methods. For example, the initial SCOD of BS at initial $\mathrm{pH}$ of 11.5 was the highest $(3048.63 \mathrm{mg} / \mathrm{L})$ and that of TS was the second highest $(2442.05 \mathrm{mg} / \mathrm{L})$. It also suggested that the initial SCODs of AS and BS were affected by the initial $\mathrm{pH}$. It was reasonable since the organics of AS and BS were solubilized at acid and alkaline conditions, respectively. The statistical analysis (made using SPSS 13.0) showed that the hydrogen yield of pretreated sludge had significant correlation with its SCOD and the Pearson correlation coefficent was 0.846 .

\subsection{Production of methane}

The hydrogen accumulated in the headspace of digesters

Table 3 Kinetic parameters of hydrogen production from sludge samples

\begin{tabular}{|c|c|c|c|c|c|c|c|c|c|}
\hline Sludge sample & & RS & & & & & & TS & US \\
\hline Initial $\mathrm{pH}$ & 2.5 & 7.0 & 11.5 & 2.5 & 7.0 & 7.0 & 11.5 & 6.8 & 6.9 \\
\hline$P(\mathrm{~mL})$ & $-{ }^{b)}$ & 1.12 & 7.03 & - & 3.02 & 1.36 & 10.84 & 8.00 & 3.56 \\
\hline$R_{m}(\mathrm{~mL} / \mathrm{h})$ & - & 0.21 & 0.62 & - & 0.21 & 0.37 & 0.44 & 1.84 & 0.64 \\
\hline$\lambda(\mathrm{h})$ & - & 12.32 & 9.76 & - & 8.39 & 6.94 & 16.22 & 9.55 & 4.00 \\
\hline $\mathrm{MSHPR}^{\mathrm{a})}(\mathrm{mL} \mathrm{H} / \mathrm{g} \mathrm{VS} \cdot \mathrm{h})$ & - & 0.15 & 0.67 & - & 0.23 & 0.40 & 0.47 & 1.98 & 0.69 \\
\hline Hydrogen yield (mL $\mathrm{H}_{2} / \mathrm{g} \vee S$ ) & - & 1.21 & 7.57 & - & 3.25 & 1.46 & 11.68 & 8.62 & 3.83 \\
\hline
\end{tabular}

a) Maximum specific hydrogen production rate; b) not analyzed. 
was consumed in the last stage of anaerobic fermentation (Figure 1). Many researchers have reported similar results ${ }^{[10-12]}$ and methanogenesis is believed to be the main hydrogen consuming action in the anaerobic digestion of sludge ${ }^{[2]}$. Figure 2 summarizes the changes of methane yields in the anaerobic fermentation of the four pretreated sludge samples. No methane could be detected in the anaerobic fermentations of BS and TS, which suggests that the alkaline pretreatment and the thermal pretreatment could kill methanogens or inhibited their activities which could not recover with the change of environment condition. Methane was also not detected in the systems added with sludge at initial $\mathrm{pH}$ of 2.5 and 11.5. Since the methanogenesis decreases or ceases when ambient $\mathrm{pH}$ is lower than 6.3 or higher than $7.8^{[23]}$, it was expectable that the activity of methanogens was inhibited under the $\mathrm{pH}$ of 2.5 and 11.5. Methane was produced from the AS and RS at initial $\mathrm{pH}$ of 7.0 and US. Obviously, the acid pretreatment could inactivate methanogens, but the activity of methanogens would recover with the change of environmental $\mathrm{pH}$. Ultrasonic pretreatment could not inhibit the activity of methanogens. The experimental results suggested that the influences of the four pretreatments on the methanogens were different. This was reasonable since the function mechanisms of the four pretreatments on bacteria are different: acid pretreatment are depended on the free $\mathrm{H}^{+}$, alkaline pretreatment depended on the free $\mathrm{OH}^{-}$, thermal pretreatment depended on the high temperature and ultrasonic pretreatment depended on the temperature and the shear produced in the sonication ${ }^{[1,9]}$. Although there was no methane production in anaerobic fermentation of some sludge samples, the hydrogen consumption also occurred in the last stage of the fermentation because there were other hydrogen-consum-

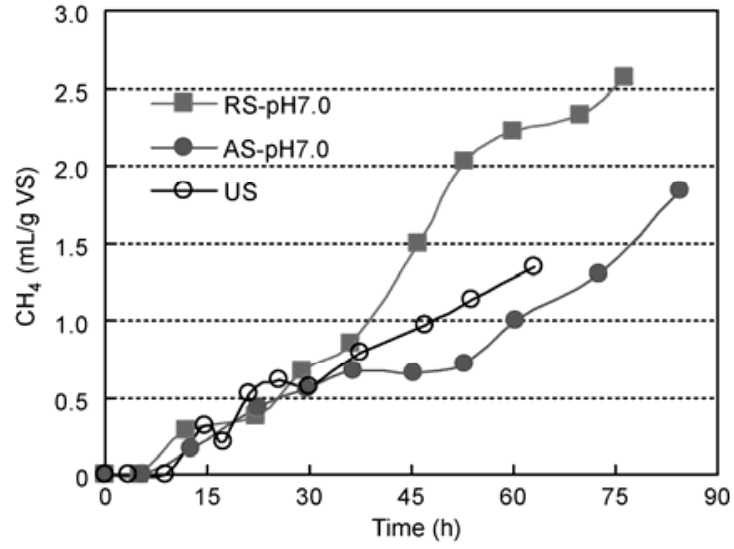

Figure 2 Methane yields of various pretreated sludge samples at various initial $\mathrm{pH}$.

ing functions like homoacetogenesis, sulfate reduction, propionic acid production, and so on.

\subsection{Production of VFA}

The volatile fatty acids (VFA) were produced in the anaerobic fermentation of sludge and the results are summarized in Table 4 (sampling time was $76.5 \mathrm{~h}$ ). The VFA were mainly composed of acetate $(45 \%-76 \%)$ and butyrate $(12 \%-22 \%)$, being very different from most studies of carbohydrates. The compositions of VFA are similar to the former researches ${ }^{[10-12]}$. The complicated organic components of the four kinds of pretreated sludge, which were degraded in the anaerobic fermentation, were the reason for the different compositions of VFA. The results in Table 4 suggest that the production of VFA and their composition in the process of hydrogen fermentation were affected by the pretreatment methods. For example, the production of VFA from BS was the maximum at initial $\mathrm{pH}$ of 11.5 and that from raw sludge was the minimum at initial $\mathrm{pH}$ of 7.0 (excluding those undetermined). Table 4 also shows that the production

Table 4 VFA production at various initial $\mathrm{pH}(76.5 \mathrm{~h})$

\begin{tabular}{|c|c|c|c|c|c|c|c|}
\hline Sludge & Initial $\mathrm{pH}$ & VFA (mg/L) & $\mathrm{HAc}^{\mathrm{a})}(\%)$ & $\operatorname{HPr}^{b)}(\%)$ & $\mathrm{HBu}^{\mathrm{c})}(\%)$ & $\mathrm{HPe}^{\mathrm{d})}(\%)$ & $A / B^{e)}$ \\
\hline \multirow[t]{3}{*}{ RS } & 2.5 & - & - & - & - & - & - \\
\hline & 7.0 & 287.13 & 76.20 & 8.76 & 6.64 & 8.38 & 11.5 \\
\hline & 11.5 & 929.55 & 53.61 & 19.59 & 15.96 & 10.85 & 3.4 \\
\hline \multirow[t]{2}{*}{ AS } & 2.5 & - & - & - & - & - & - \\
\hline & 7.0 & 797.82 & 66.67 & 13.16 & 13.18 & 6.97 & 5.1 \\
\hline \multirow[t]{2}{*}{ BS } & 7.0 & 1666.14 & 45.51 & 21.56 & 21.85 & 1.12 & 2.1 \\
\hline & 11.5 & 2117.75 & 63.00 & 18.19 & 12.01 & 6.81 & 5.3 \\
\hline TS & 6.8 & 1142.25 & 66.23 & 11.10 & 13.46 & 9.21 & 4.9 \\
\hline US & 6.9 & 820.02 & 60.71 & 18.18 & 12.39 & 8.72 & 4.9 \\
\hline
\end{tabular}

a) Acetate; b) propionate; c) butyrate; d) pentanoate; e) acetate/butyrate; -, not determined. 
and the composition of VFA were sensitive to the initial $\mathrm{pH}$. For instance, the production of VFA from BS at initial $\mathrm{pH}$ of 11.5 was higher than that at initial $\mathrm{pH}$ of 7.0. VFA could be used to produce methane or hydrogen in the post-treatment ${ }^{[2,23,24]}$. The more the VFA are, the more methane or hydrogen will be produced. So, the remainder of BS after biohy- drogen production could produce the most methane or hydrogen in the posttreatment and that of TS is the next. By the way, for the sludge pretreated by acid and alkaline, namely AS and $\mathrm{BS}$, it is necessary to consider the ion, which would increase the cost of the post-treatment, while this problem does not exist for the TS and US.

\subsection{Change of $\mathrm{pH}$}

The changes of the four pretreated sludge $\mathrm{pH}$ during the anaerobic fermentation are summarized in Figure 3. The change of $\mathrm{pH}$ is caused by the production of VFA and $\mathrm{NH}_{4}^{+}-\mathrm{N}$. For raw sludge at initial $\mathrm{pH}$ of 11.5 , the decreases of $\mathrm{pH}$ were rapid and the $\mathrm{pH}$ decrease rate was faster than that of $\mathrm{BS}$ at the same initial $\mathrm{PH}$, while the

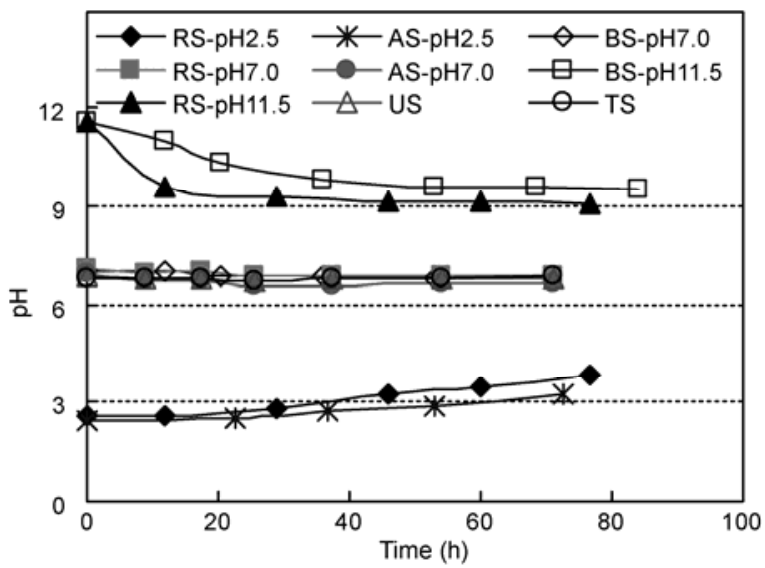

Figure 3 Changes of $\mathrm{pH}$ in the anaerobic fermentation for various pretreated sludge

1 Weemaes M P J, Verstraete W H. Evaluation of current wet sludge disintegration techniques. J Chem Technol Biotechnol, 1998, 73: $83-92$

2 Parkin B G F, Owen W. Fundamentals of anaerobic digestion of wastewater sludges. J Environ Eng ASCE, 1986, 112: 867-920

3 Reith J H, Wijffels R H, Barten H. Bio-methane \& Bio-hydrogen. Status and Perspectives of Biological Methane and Hydrogen Production. Dutch biological hydrogen foundation. Wageningen. 2003. $103-123$

4 Hawkes F R, Dinsdale R, Hawkesb D L, et al. Sustainable fermentative hydrogen production: change for process optimization. Int J Hydrogen Energ, 2002, 27: 1339-1347 end $\mathrm{pH}$ was above 9.0. For neutral initial $\mathrm{pH}$, the changes of $\mathrm{pH}$ were very for all pretreated sludge samples. The $\mathrm{pH}$ of sludge samples at initial $\mathrm{pH}$ of 2.5 increased. The terminal $\mathrm{pH}$ of raw sludge at initial $\mathrm{pH}$ of 11.5 and 2.5 was 9.05 and 3.85, respectively, which could also explain why there was no methane production under such initial $\mathrm{pH}$. The differences in the change of $\mathrm{pH}$ were concerned with the SCOD of the sludge samples since the productions of VFA and $\mathrm{NH}_{4}^{+}-\mathrm{N}$ is the result of organics (SCOD) degradation.

\section{Conclusions}

(1) All of the four pretreatments, acid, alkaline, thermal and ultrasonic pretreatments, could select hydrogenproducing microorganisms from the microflora of sludge and enhance hydrogen yield of sludge by anaerobic fermentation without extra-seeds. The hydrogen yield of alkaline pretreated sludge at initial $\mathrm{pH}$ of 11.5 was the maximal (11.68 $\mathrm{mL} \mathrm{H}_{2} / \mathrm{g} \mathrm{VS}$ ) and that of thermal pretreated sludge was the next $\left(8.62 \mathrm{~mL} \mathrm{H}_{2} / \mathrm{g} \mathrm{VS}\right)$.

(2) All of the four pretreatments could increase the SCOD of sludge and the hydrogen yield of pretreated sludge had a significant correlation with its SCOD.

(3) Both alkaline pretreatments and thermal pretreatment could fully inhibit the activity of methanogens, while acid pretreatment and ultrasonic pretreatment could not.

(4) The VFA production of alkaline pretreated sludge (at initial $\mathrm{pH}$ of 11.5) was the maximum and that of thermal pretreated sludge is the next. The remainder of alkaline pretreated sludge (at initial $\mathrm{pH}$ of 11.5) after biohydrogen production could produce the most methane or hydrogen in the post-treatment and that of thermal pretreated sludge was the next.

5 Chen C C, Lin C Y, Lin M C. Acid-base enrichment enhances anaerobic hydrogen production process. Appl Microbiol Biot, 2002, 58: $224-228$

6 Duangmanee T, Padmasiri S I, Simmons J J, et al. Hydrogen production by anaerobic microbial communities exposed to repeated heat treatments. Wat Environ Res, 2007, 79: 975-983

7 Lay J J, Fan K S, Chang J, et al. Influence of chemical nature of organic wastes on their conversion to hydrogen by heat-shock digested sludge. Int J Hydrogen Energ, 2003, 28: 1361-1367

8 Kim J, Park C, Kim T, et al. Effects of various pretreatment for enhanced anaerobic digestion with waste activated sludge. J Biosci Bioeng, 2003, 95: 271-275 
9 Muller J A. Prospects and problems of sludge pre-treatment processes. Wat Sci Technol, 2001, 44: 121-128

10 Cai M L, Liu J X, Wei Y S. Enhanced biohydrogen production from sewage sludge with alkaline pretreatment. Environ Sic Technol, 2004, 38: $3195-3202$

11 Xiao B Y, Liu J X. Effects of thermally pretreated temperature on bio-hydrogen production from sewage. J Environ Sci, 2006, 18: 6-12.

12 Xiao B Y, Liu J X. pH dependency of hydrogen fermentation from alkaline pretreated sludge. Chin Sci Bull, 2006, 51: 399-404.

13 Wang C C, Chang C W, Chu C P, et al. Hydrogen production from wastewater sludge using a Clostridium strain. J Environ Sic Heal A, 2003, 38: 1867-1875

14 Wang $\mathrm{C} \mathrm{C}$, Chang $\mathrm{C} \mathrm{W}$, Chu $\mathrm{C} \mathrm{P}$ et al. Producing hydrogen from wastewater sludge by Clostridium bifermentans. J Biotechnol, 2003, 102: $83-92$

15 Moosvi S, Madamwar D. An integrated process for the treatment of CETP wastewater using coagulation, anaerboic and aerobic process. Bioresource Technology. 2007, 98: 3384-3392

16 Lowry O H, Rosebrough N J, Farr A L, et al. Protein measurement with the Folin phenol reagent. J Biol Chem, 1951, 1993: 265-275
17 Dubois M, Gilles K A, Hamilton J K, et al. Calorimetric method for determination of sugars and related substances. Anal Chem, 1956, 28: $350-356$

18 APHA. Standard Methods for the Examination of Wastewater. 20th ed. APHA, AWWA, WPCF, Washington, D.C., USA. 1998

19 Lay J J. Biohydrogen generation by mesophilic anaerobic fermentation of microcrystalline cellulose. Biotechnol Bioeng, 2001, 74 $280-287$

20 Fang $\mathrm{H}$ H P, Liu H. Effect of $\mathrm{pH}$ on hydrogen production from glucose by a mixed culture. Bioresource Technol, 2002, 82: 87-93

21 Kim J, Park C, Kim T H, et al. Effects of various pretreatments for enhanced anaerobic digestion with waste activated sludge. J Biosci Bioeng, 2003, 95: 271-275

22 Hussy I, Hawkes F R, Dinsdale R, et al. Continuous fermentative hydrogen production from a wheat starch co-product by mixed microflora. Biotechnol Bioeng, 2003, 84: 619-626

23 Gerardi M H. The Microbiology of Anaerobic Digesters. John Wiley \& Sons, Inc. press. 2003. 99-105

24 Hawkes F R, Hussy I, Kyazze G, et al. Continuous dark fermentative hydrogen production by mesophilic microflora-Principles and progress. Int J Hydrogen Energ, 2007, 32: 172-184 